\title{
Construction and Practice of Teaching System of Animation Products Design Project of Animation Major Driven by Original Brand*
}

\author{
Ran Zhao \\ Dalian Neusoft University of Information \\ Dalian, China
}

\begin{abstract}
In the era of cultural innovation and mass entrepreneurship, the animation products design as an integral part of the cultural and creative industries gradually gains attention with the vigorous development of China's film and television culture industry. This article illustrate the effectiveness of its teaching and promotion methods from the aspects of value and meaning of the original brand, innovation point in teaching of animation products design project for animation major, and construction and practice, expecting to contribute practical and theoretical experience to the construction of animation-related majors in colleges and universities.
\end{abstract}

Keywords-original brand; animation products; construction and practice

\section{INTRODUCTION}

In 2016, the General Office of the State Council's several opinions on promoting the development of the animation industry in China pointed out that through policy promotion, under the impetus of cultural innovation, media innovation, and technological innovation, we can promote the development of the entire animation industry chain, and strengthen the design and production of animation peripheral derivatives. At the same time, 3D Print technology, digital picture book of mobile communication client, VR virtual reality, and interactive display of AR augmented reality, and fusion of art and technology are the development trends of contemporary animation products design. It has been the consensus the most valuable and potential part of the whole animation industry chain is animation products. Teachers in the animation major course group should boldly innovate and practice combining the three aspects of national policy, college teaching reform and industrial development, and achieve teaching value with a promotion value and significance in theory, technology, culture and practice.

\section{BASED ON THE MEANING OF ORIGINAL BRAND}

In terms of theory, the construction of the curriculum will inevitably be based on the standards of the cultural industry

*This article is the result of the Project of the "13th Five-Year Plan" project for Educational Science of Liaoning Province. The title of the project is "The Study of the Application of Animation Professional Project Driven by Original Brand", subject number JG17DB045. and the animation industry to cultivate talents with good practical ability, ability to innovate and entrepreneurship of patriotism, humanistic values, and original character. In terms of technology, attentions should be paid on the development of science and technology and 3D printing technology, augmented reality technology, mobile communication technology, and APP development technology should be introduced into the animation products design, and is leading the training of domestic animation talents. In the aspect of cultural communication and inheritance, based on the cultivation of applied talents, we should not forget the belief in the cultural inheritance and the original will. The teachers in the course group can improve the connotation construction and infiltrate Chinese traditional culture, folk culture, and humanistic care in the classroom teaching. Driven by the character "originality", they should integrate the deep experience and feelings of the Chinese spirit and culture into the works. In terms of practical significance, the teachers of the course group set off from the "three-dimensional modeling" school-level exquisite class and complete the reform and practice of the animation products design projects, the design and development of the traditional folk-class cartoon cultural and creative products, the exploration and practice of the training mode of the innovation experimental class of animation major, the design and development of film and television culture animation derivative products, research and release of AR augmented reality picture book, the research and development of cartoon original brand "Donki", and the application research of combination of 3D printing technology and animation peripheral products. They also promote the teaching results all-round in multi-angle through the mobile platform, school exhibitions and other media, which is highly praised. The previous students' practical innovation ability has also been significantly enhanced. They have won many awards and patent applications in national competitions, and the employers of graduates have also highly evaluated the professional ethics and practical ability of students in this major. 


\section{THE INNOVATION OF TEACHING OF ANIMATION PRODUCTS DESIGN PROJECT}

Through the teaching of animation surrounding design project, it can solve the problem of accurate positioning of innovative and entrepreneurial application talents of animation majors; solve the problem of "original" consciousness in cultivating talents of cultural and creative industries; solve the problem of construction of TOPCARES-CDIO animation products design project group; solve the problem of cultivating students' creative and entrepreneurial abilities; solve the problem of the disconnection between "teaching and industry" and seamless integration of "school and enterprise"; solve the problem of individuation cultivation of students' ability; solve the problem of cross-border integration of teaching and technology; solve the problem of the communication and inheritance of craftsmen's spirit in teaching practice

\section{CONSTRUCTION OF TEACHING OF ANIMATION PRODUCTS DESIGN PROJECT FOR ANIMATION MAJOR}

\section{A. To Activate the Students' Maker Gene with the Original Animation Brand as the Driver}

- For training of theoretical and practical abilities driven by original animation brands, the original animation is the embodiment of "artisan spirit". In the teaching process, teachers and students thoroughly analyze the success and failure cases of original animation brands and guide students to make big data analysis through CNKI, Google academics and other databases and improve the conception and design of the work continuously by relying on the implementation of studios and laboratories to successfully transform thinking-real objectproduct-brands combining "four new ideas".

- Center Transformation of "3-Center-ChangeCreative": Activate student's maker gene 3-CenterChange-Creative is a teaching model based on OBE learning outcomes, which transforms teachercentered to student-centered, transform the center of thinking, designing, implementing, and operating to OBE learning outcomes and transform classroom teaching centering to practical projects centering. Therefore, the integrating teaching model with project as orientation and the results can test the teaching and learning effects. In this process, students can experience the sense of accomplishment brought by the creation and their maker gene can be activated.

\section{B. Construction of a Curriculum Group System Guided by} Animation Products Design Projects

- Basic courses, practical courses, and first-class projects run through the entire professional ability training. With animation products design projects as the orientation, from three-dimensional shaping, art foundation, three-dimensional modeling, digital sculpture, 3D printing project practice, and graduation design, etc., it can make effective evaluation of the work, and portfolio design and graduation design create an original cartoon brand, which is throughout the professional ability training.

- To build a practical teaching system based on the deep cooperation of "production, study and research". After clarifying the actual needs of the industry, in the design of the integrated curriculum system, we carefully designed practical projects. Each project is supported by a number of major courses. With the guidance of the project training, the integrated curriculum system that integrates the curriculum and the project and simultaneously trains knowledge, ability and quality is realized"[1]. We actively establish the SOVO (College Entrepreneurship Center) company. The outstanding works in the project rely on the Digital Arts Department's space innovation and entrepreneurship experience platform to deepen cooperation in production, education and research.

- Multi-platform cooperation and animation project design real project practice, with the help of crowd funding platforms, actively promote students' works, and at the same time students' cartoon original brand can be tested on e-commerce platform such as Tencent and Ali platform so as to really face the industry and face market. In this process, some of the students' works are approved by the commercial market. Under the customer's requirements, according to the customization requirements, they make conception, design, implementation, and production and good social effects are gained. It not only expands the social reputation of the project teaching results, but also lets the students get the first pot of gold, and stimulates the passion for innovation and entrepreneurship.

\section{To Develop Students' Extracurricular Innovation and Entrepreneurship through Interaction between Research and Study, Relying on High-level Events and Horizontal and Vertical Projects}

Professional teachers build research teams combining their own research direction, pay attention to students' expertise, and let students to participate in targeted horizontal and vertical topics; at the same time, they can choose targeted social professional competitions and actively organize and guide students to declare mass entrepreneurship projects.

\section{To Carry out Multi-level and Multi-form Training and \\ Exchanges, and Strengthen Animation Products Design Projects through "Cross-media" Integration Promotion}

In order to practically understand and master the "four new ideas" of industries in which they are located, and enhance the awareness of innovation and entrepreneurship, relevant experts from the four major academies of the art and first-tier entrepreneurs and designers are invited to give lectures and training to our university. The teachers of the project team also traveled across the country to observe 
exhibitions in the animation industry, participate in academic conferences, and conduct exchange learning and enterprise training. In the promotion of results, cross-school joint animation products design lectures can be held to promote student achievement in animation products design projects with the help of mobile platforms and mobile clients. The APP Surprising series 3D digital picture books researched and developed independently gain high praise in children's cognitive picture books.

\section{E. To Improve the Quality of Theoretical Research Results,}

Form Excellent Teaching Materials, Actively Participate in International Conferences Related to Art Education, and Publish Relevant Research Literature

They should actively carry out the preparation of related teaching materials, focus on daily archiving, form electronic archives, continuously accumulate and form influential teaching materials in the professional field combining the "13th Five-Year Plan", actively participate in international conferences related to high-end art education, and innovate and practice the international leading educational ideas in classroom.

\section{The Teaching Practice of Animation Products DESIGN PROJECT OF ANIMATION MAJOR}

\section{A. Initiating the Teaching System of Animation Products Design Taking TOPCARES-CDIO Project as Orientation}

This course system was started in 2009 by the Department of Digital Art of Dalian Neusoft Institute of Information. It was formally established in 2010. In 2011, it represented the second-level project of the Digital Art Department and participated in the school's TOPCARESCDIO engineering education teaching reform. The course is a pioneer in the domestic animation profession in colleges and universities nationwide.

\section{B. The Original Animation Brand "Donki \& Cutey" Drives Entrepreneurship Education Practice}

"Donki\&Cutey" is an animation brand independently developed by teachers of the course group, of which the founding teacher is Li Xuesong, a teacher of digital art major in Dalian Neusoft Institute of Information. Li Xuesong leads student students to participate in Donki image design, illustration creation, 2D picture book design, and 3D animation production, Unity augmented reality technology, digital sculpture and 3D printing, digital picture book layout design and other links. The commercial simulation of operation and management in the whole process fully exercised the students' creative and innovation capabilities, and also stimulated their "artisan spirit" and entrepreneurial passion.

\section{Relying on the "Incubator" of the Art Creation Space Project and the Combination of Production, Teaching and Research}

Art creation Space is a self-owned display and sales product platform of Dalian Neusoft Institute of Information. With the help of art creation space platform, the original animation brand IP is hatched into an "animation expression, animation game, entity derivative and other innovative applications"[2] achieving copyright provision, production, channel promotion, multi-win-win situation, realizing integrated applied teaching results from classroom to market, and helping the organic integration and sublimation of creativity, innovation, entrepreneurship.

\section{3D Printing, AR Augmented Reality, and APP Technology Integration and Innovation}

The systematic explanation of 3D printing theory and practical operation in professional courses is an innovation in domestic animation professional education. At the same time, combining with AR augmented reality technology to create interactive 3D digital picture books achieve the cross-border integrated development between AR augmented reality industry and education. The self-developed "mobile phone APP" client has been officially released on the Android system and the Apple iOS system.

\section{E. Bilingual Teaching Develops International Vision of Teachers and Students}

Two teachers in the project team were awarded the "Liaoning Province Bilingual Teacher Qualification", and one of them passed the English ability recognition in the school. The bilingual "Bilingual Experimental Course" was successfully opened and the original English version of the teaching material was introduced, with a test bank, which lays the foundation for broadening the international vision for teachers and students of this major. At the same time, the teachers and students of Animation products Course Project Group of animation major actively sought international cooperation and released the latest creative works in the famous CG community, aroused topic discussion and actively improved and completed the project results according to the comments of the industry.

\section{F. The Doll Design Contest Assists in Practical Innovations, and Competitive Products Continue to Emerge in the Exhibition Area of "Animation Products" for Seven Consecutive Years}

The Animation major of the Digital Art Department of Dalian Neusoft Institute of Information holds an annual animation doll design contest to help solve the problem of disconnection between innovation and entrepreneurship education and practice. In addition, the Golden Autumn Exhibition and the Digital Spring Exhibition for nine consecutive years have all set up display platforms and exhibition boards for anime product. Each time, they attract visitors from both inside and outside the school. 
G. Receiving the Approval of the Practice Base for University Students in Liaoning Province, and the Student's Practical Ability Has Been Recognized by the Enterprise

After four years of continuous construction, it was awarded the Liaoning University Practical Education Base in 2012. It establishes Tongji Venture Valley in the Hi-tech Park in 2016 and "Dalian Museum of Art", which built a good external communication space for students.

\section{H. Setting the Topic of Graduation Design of Animation Derivative Products and Test the Teaching Results through the Coping Stone Project}

Since 2016, the topic of "Animated Derivatives" design was set in the topic of graduation design to the all-round test the teaching quality in teaching, assessment, and graduation design. This is a bold innovation and practice in the training system for professional cartoon talents in China.

\section{Actively Promoting Teaching Achievements through \\ Teacher Training in Liaoning Province}

Since 2014, Dalian Neusoft Institute of Information has organized four rounds of teacher training courses such as "Animation Products Design Project Training" and "Animation products Design and 3D Printing Project Training" in Liaoning Province. Higher vocational college teachers in Liaoning Province have gathered together and the training site has a strong atmosphere of learning. Many students practice late into the night. During the process of study, some students with zero bases can gradually conceive, design and implement a complete animation product design work. The good teaching style and good learning experience form good word-of-mouth effect and promote the publicity of teaching achievements.

\section{J. To Cultivate and Practice the Socialist Core Values, and Inherit and Develop Excellent Traditional Culture}

We pay attention to the cultivation of socialist core values, emphasize cultural influence, use Chinese dreams and positive energy to agglomerate consensus, and enhance students' awareness of cultural heritage and protection. Several works implicated in national implication obtained national first prize in the National Computer Design Contest 2014-2015 national group competition.

\section{CONCLUSION}

In the three "Five-Year Plan" of China, "Culture Innovation Enhances National Cultural Soft Power," "innovative entrepreneurship education" and "Employment Drives Employment" are at the core. They adhere to the national original animation brand and encourage students to develop innovative, and actively participate in enterprises practice. Under the background of cultural innovation and technological entrepreneurship, we welcome the arrival of China 2025 and contribute our strength to the great rejuvenation of the Chinese nation.

\section{REFERENCES}

[1] Zhou Guoshun, Zhang Yang, Han Ti, Lin Baowei, Sun Xiaoling et al Reform of the Talents Training Program for Intelligent Science and Technology in the CDIO Mode [J] Computer Education. 2015.9. 周 国顺.张阳.韩媞.林宝尉.孙晓凌等.CDIO 模式下智能科学与技术专 业人才培养方案改革[J]计算机教育.2015.9.

[2] Li Wenjie. Teaching Reform and Research in the Development and Construction of 3D Animation Innovation and Entrepreneurship Curriculum[J].2016.3. 李文杰.三维动画创新创业课程开发建设中 的教学改革与研究.2016.3. 